\title{
ДОСЛІДЖЕННЯ КОГНІТИВНОГО КОМПОНЕНТА ЦІННІСНИХ ОРІЕНТАЦІЙ СТУДЕНТІВ-ВОЛОНТЕРІВ
}

\author{
Подолянчук Діана \\ Вінницький державний педагогічний університет імені Михайла \\ Коцюбинського, \\ м. Вінниця, Україна \\ shahinadi@gmail.com \\ ORCID: https://orcid.org/0000-0003-3772-4523
}

Mema. Статтю присвячено дослідженню ціннісних орієнтацій студентів педагогічного університету. Мета статті - представити результати емпіричного вивчення особливостей когнітивного компонента ціннісних орієнтацій студентів педагогічного університету, які беруть участь у волонтерському русі.

Memоди. Вивчення теоретичних аспектів проблеми здійснено 3 використанням загальнонаукових методів (аналізу, синтезу, узагальнення). Емпіричне дослідження ціннісних орієнтацій студентів виконано за допомогою методики вивчення індивідуальних цінностей Шварца, адаптованої В. М. Карандашевим. Обробку отриманих результатів здійснено за допомогою методів математичної статистики (критерій Фішера, критерій Стьюдента).

Результати. Аналіз теоретичних джерел дозволив констатувати важливість ціннісних орієнтацій як особистісних чинників волонтерської діяльності студентів. При цьому в структурі ціннісних орієнтацій важлива роль належить когнітивному компоненту, що відображає нормативні ідеали студентів, їхні ціннісні уявлення («цінності-знання»), що тією чи іншою мірою впливають на особистість. У результаті проведеного дослідження визначено абсолютні показники середніх значень різних типів нормативних цінностей та їхній ранг для студентів-волонтерів i студентів, які не практикували волонтерську діяльність. Порівняльний аналіз із застосуванням критеріїв Фішера і Стьюдента дав змогу визначити відмінності у ставленні обох груп студентів до різних типів цінностей.

Висновки. Проведене дослідження засвідчило, що у ставленні до більшості типів нормативних цінностей (безпека, конформність, гедонізм, універсалізм, влада, традиції) між студентами-волонтерами і тими, що не беруть участі у волонтерській діяльності, відсутні статистично значущі відмінності. 3'ясовано, що найбільш значущими для всіх студентів $є$ цінності доброзичливості та безпеки. Основними групами цінностей, ставлення до яких відрізняє студентівволонтерів від тих, які не займаються волонтерською діяльності, є досягнення

ISSN 2308-3743 (Online), ISSN 2227-1376 (Print)

(C) Подолянчук Д., 2021. Ця стаття відкритого доступу на умовах CC BY-NC 4.0 
та доброзичливість. У ставленні до інших груп цінностей (самостійність, стимуляція) також спостерігаються певні відмінності між студентами досліджуваних груп. Проте за помітної різниці в абсолютних середніх показниках ці відмінності не досягають рівня статистичної значущості. Варто також відзначити достатній рівень обізнаності сучасних студентів з різними типами нормативних цінностей.

Ключові слова: цінності, нормативні цінності, ціннісні орієнтації, волонтер, волонтерська діяльність, студент, методика Шварца.

\section{Podolianchuk Diana. The research of the cognitive component of value orientations of volunteering students.}

Purpose. The article is devoted to the study of value orientations of students of the pedagogical university. The purpose of the article is to present the results of an empirical study of the features of the cognitive component of value orientations of students of the pedagogical university who participate in the volunteer movement.

Methods. The study of theoretical aspects of the problem was carried out using general scientific methods (analysis, synthesis, generalization). The empirical study of students' value orientations was carried out using the method of studying the individual values of Schwartz, adapted by V. M. Karandashev. The obtained results were processed using the methods of mathematical statistics (Fisher's test, Student's test).

Results. The analysis of theoretical sources allowed to state the importance of value orientations as personal factors of students' volunteer activity. At the same time, an important role in the structure of value orientations belongs to the cognitive component, which reflects the normative ideals of students, their values ("valuesknowledge"), which to some extent affect the personality. As a result of the research, the absolute indicators of average values of different types of normative values and their rank for student-volunteers and students who are not engaged in volunteer activities are determined. Comparative analysis and the application of Fisher's and Student's criteria made it possible to identify differences in the attitudes of both groups of students to different types of values.

Conclusions. The conducted study showed that there are no statistically significant differences concerning most types of normative values (security, conformity, hedonism, universalism, power, and traditions) between volunteering students and those who do not participate in volunteering at all. The values of benevolence and security are most important to all students. The main groups of values, the attitude to which distinguishes volunteering students from those who do not volunteer, are achievement and benevolence. With other groups of values (independence, stimulation) there are also some differences between students of the studied groups. However, with a significant difference in absolute averages, these differences do not reach the level of statistical significance. It is also worth noting the sufficient level of awareness of modern students with different types of normative values. 
Keywords: values, normative values, value orientations, volunteer, volunteer activity, student, Schwartz's method.

\section{Подолянчук Диана. Исследование когнитивного компонента ценностных ориентаций студентов-волонтеров.}

Цель. Статья посвящена исследованию ценностных ориентаций студентов педагогического университета. Цель статьи - представить результаты эмпирического изучения особенностей когнитивного компонента ценностных ориентаций студентов педагогического университета, участвующих в волонтерском движении.

Memoдb. Изучение теоретических аспектов проблемы осуществлялось с использованием общенаучных методов (анализа, синтеза, обобщения). Эмпирическое исследование ценностных ориентаций осуществлялось с помощью методики изучения индивидуальных ценностей Шварца, адаптированной В. М. Карандашевым. Обработка полученных результатов происходила с помощью методов математической статистики (критерий Фишера, критерий Стьюдента).

Pезультаты. Анализ теоретических источников позволил констатировать важность ценностных ориентаций как личностных факторов волонтерской деятельности студентов. При этом в структуре ценностных ориентаций важная роль принадлежит когнитивному компоненту, отражающему нормативные идеалы студентов, их ценностные представления («ценности-знания»), в той или иной степени влияющие на личность. В результате проведенного исследования определены абсолютные показатели средних значений различных типов нормативных ценностей и их ранг для студентов-волонтеров и студентов, не занимающихся волонтерской деятельностью. Сравнительный анализ с применением критериев Фишера и Стьюдента позволил определить различия в отношении обеих групп студентов к различным типам ценностей.

Bbыводы. Проведенное исследование показало, что в отношении к большинству типов нормативных ценностей (безопасность, конформность, гедонизм, универсализм, власть, традиции) между студентами-волонтерами и теми, кто не принимает участия в волонтерской деятельности, отсутствуют статистически значимые различия. Установлено, что наиболее значимыми для всех студентов ценностями есть доброжелательность и безопасность. Основными группами ценностей, отношение к которым отличает студентовволонтеров от тех, кто не занимается волонтерской деятельностью, является достижение и доброжелательность. В отношении к другим группам ценностей (самостоятельность, стимуляция) также наблюдаются определенные различия между студентами исследуемых групп. Однако при заметной разнице в абсолютных средних показателях эти различия не достигают уровня статистической значимости. Стоит также отметить достаточный уровень осведомленности современных студентов с различными типами нормативных ценностей. 
Ключевые слова: ценности, нормативные ценности, ценностные ориентации, волонтер, волонтерская деятельность, студент, методика Шварца.

Вступ. Однією 3 тенденцій суспільно-політичного життя в сучасному світі $\epsilon$ активний розвиток волонтерського руху. Волонтерство гармонійно вбудовується не лише в громадські, а й у державні інститути, отримуючи всебічну законодавчу та нормативну підтримку. Правове регулювання волонтерської діяльності потрібне для того, щоб гарантувати добровольцям захист i виокремити їх iз загалу найманих працівників (Буздуган, Никонович, 2013: 9). У багатьох європейських країнах уряди ініціюють і просувають низку заходів на підтримку волонтерської діяльності (Boros, Marian, Mateevici, 2019: 23).

За свідченням науковців, у багатьох країнах світу, в тому числі і в Україні (Водяна, 2020: 103; Тохтарова, 2014), найчисельнішою групою серед волонтерів є здобувачі вищої освіти. Зазвичай студенти мають різну мотивацію, коли розпочинають волонтерську діяльність. Основні їхні очікування - змінити ситуацію в країні, розвинути кар’єру та завести друзів. Мотивація студентів-волонтерів може також бути альтруїстичною (Haski-Leventhal, et al., 2020: 122).

Демонструючи доброзичливість, співчуття, наполегливість, відповідальність, студенти активно долучаються до різноманітних волонтерських проектів. Зазвичай такі проекти стосуються допомоги людям похилого віку, дітям-сиротам, особам 3 інвалідністю та всім тим, хто опинився у скрутному становищі. Достатньо поширеними останнім часом стали екологічні проекти та проекти, пов'язані 3 організацією різноманітних масових заходів (конференцій, семінарів, фестивалів, виставок, спортивних змагань тощо). Поступово набирають обертів різноманітні форми онлайн-волонтерства (Колотило, 2020).

Динамічний розвиток волонтерського руху та активна участь у ньому студентства зумовлюють потребу у вивченні соціальнопсихологічних чинників i механізмів цього процесу. Серед таких чинників особлива роль належить ціннісним орієнтаціям студентів, що визначають спрямованість їхньої поведінки.

Очевидно, що особистісні цінності та волонтерська діяльність тісно взаємопов'язані. Дж. Есмонд i П. Данлоп серед основних особистісних чинників волонтерської діяльності виокремлюють 
цінності (Esmond, Dunlop, 2004: 51). Е. Кларі та М. Снайдер також вважають особистісні цінності потенційно важливими факторами волонтерства (Clary, Snyder, 1999: 157). Цінності розглядаються як організаційно-управлінські інструменти, які використовують менеджери організацій (Akın, 2018: 174), зокрема й під час волонтерської діяльності. Саме волонтерство актуалізує найблагородніші цінності людства - мир, свободу, безпеку (Boros, Marian, Mateevici, 2019: 19).

Варто зазначити, шо поняття «цінності» та «ціннісні орієнтації» не тотожні. На думку А. Павліченка, ціннісні орієнтації - основні форми функціонування цінностей, що характеризують момент переходу останніх у діяльність (Павліченко, 2005: 105). I. Федух також розмежовує ці поняття. Цінності він розуміє як узагальнені уявлення, ідеали, стереотипи суспільної та індивідуальної свідомості, що функціонують як ідеальні критерії оцінки й орієнтації особистості, а ціннісні орієнтації - як відображення у свідомості людини цінностей, що визнаються нею як стратегічні життєві цілі та загальні світоглядні орієнтири, які формуються на базі співвіднесення особистісного досвіду з поширеними у соціумі зразками культури (Федух, 2011).

У сучасній психології ціннісні орієнтації розглядаються як відносно стійкі, соціально обумовлені, вибіркові ставлення людини до сукупності матеріальних і духовних суспільних благ та ідеалів, які розглядаються як предмети, цілі або засоби для задоволення потреб життєдіяльності особистості (Долинська, Максимчук, 2008: 12). Сформована система ціннісних орієнтацій забезпечує гармонію внутрішнього світу особистості, сприяє систематизації ії знань, норм, стереотипів поведінки та самоствердженню особистості, реалізації соціальних очікувань. Кожна із цінностей є значущою не тільки у зв'язку з іншими, але й сама по собі, як самоцінність (Панчук, 2017: 322). Знання ціннісних орієнтацій дає змогу зрозуміти відмінності у прийнятті рішень, вподобаннях і способах поведінки людей (Ak1n, 2018: 173).

Вивчення ціннісних орієнтацій студентської молоді належить до відносно самостійних напрямів соціально-психологічних досліджень. На думку В. Марчука та Н. Стаднік, ціннісні орієнтації студентів є структурним утворенням, що містить сукупність взаємопов'язаних компонентів. Зміст кожного компоненту співвідноситься 3 певної 
сферою особистості й передбачає становлення студента не лише як соціально активного суб'єкта, а й відповідального, висококваліфікованого майбутнього фахівця (Марчук, Стаднік, 2018: 186).

Ціннісні орієнтації відображають особистісно-вибіркове ставлення студентів до актуальних матеріальних i духовних суспільних цінностей, які визначають світогляд, слугують орієнтиром у житті та виступають основою для самооцінювання й оцінювання різноманітних подій, суспільних явищ i вчинків інших людей (Подолянчук, 2020: 268). Визначення ціннісних орієнтацій виявляє індивідуальну та групову прихильність до певних загальнолюдських цінностей, цілей, засобів життєдіяльності, рівня їх значущості для людини та загальної орієнтації на певний тип поведінки (Botalova, et al., 2016: 10280).

Останнім часом науковці великого значення надають вивченню структури професійних цінностей студентської молоді, виокремлюючи в ній горизонтальний та вертикальний рівні (Botalova, et al., 2016: 10286). Професійно-ціннісні орієнтації розглядаються як компоненти мотиваційної сфери особистості, що визначають спрямованість спілкування й вибіркову орієнтацію на певні аспекти професійної діяльності (Галузяк, 2009: 89).

Соціально-психологічні дослідження засвідчують, що перелік основних цінностей студентської молоді не зазнає суттєвих трансформацій упродовж навчання в закладі вищої освіти. Водночас рівень їх значущості постійно змінюється, що зумовлено впливом різних зовнішніх і внутрішніх чинників (Подолянчук, 2020: 268). У більш віддаленій часовій перспективі структура цінностей також має динамічний характер - вони змінюються від покоління до покоління, відображаючи зміну соціальних пріоритетів (Bojović, Vasilijević, Sudzilovski, 2015: 12).

Система ціннісних орієнтацій особистості має багаторівневу структуру. На думку В. Бочелюк, її вершина - це ціннісні орієнтації, пов'язані з ідеалізаціями й життєвими цілями особистості (Бочелюк, 2012: 7). У сучасному трактуванні (Москаленко, 2013: 93) внутрішня організація структури ціннісних орієнтацій особистості охоплює собою три компоненти: когнітивний (смисловий), емотивний (емоційно-оцінний) i конативний (поведінковий, діяльнісний, вольовий). Конкретизуючи зміст когнітивного компоненту, 
Ю. Сошина зазначає, що він включає в себе знання про цінності та знання-цінності (ціннісний компонент) (Сошина, 2016: 49). В. Драченко вважає, що когнітивний компонент містить систему засвоєних особистістю «соціальних знань»: понять, правил, оцінок, норм, переконань, поглядів, вірувань, цінностей (Драченко, 2016: 9).

Згідно з нашим припущенням, участь студентів у волонтерському русі пов'язана 3 певними особливостями структури їхньої спрямованості, що має відображатися, зокрема, у змісті когнітивного компоненту ціннісних орієнтацій.

Мета статті - представити результати емпіричного вивчення особливостей когнітивного компонента ціннісних орієнтацій студентів педагогічного університету, які беруть участь у волонтерському русі.

Методи та процедури дослідження. Вивчення теоретичних аспектів проблеми здійснювалось із використанням загальнонаукових методів (аналізу, синтезу, узагальнення). Для емпіричного вивчення когнітивного компоненту ціннісних орієнтацій студентів застосовано методику дослідження індивідуальних цінностей Шварца, адаптовану В. М. Карандашевим (Карандашев, 2004). Використано першу іï частину («Огляд цінностей»), яка дає змогу виокремити нормативні ідеали студентів, їхні ціннісні уявлення («цінності-знання»), що тією чи іншою мірою впливають на особистість, проте не завжди знаходять реалізацію в поведінці та практичній діяльності.

Методика Шварца діагностує десять типів цінностей: 1) влада, 2) досягнення, 3) гедонізм, 4) стимуляція, 5) самостійність, 6) універсалізм, 7) доброта, 8) традиції, 9) конформність, 10) безпека (Schwartz, 1992; Schwartz, Bilsky, 1994). Практична частина методики являє собою два списки, які містять перелік відповідно 30 та 27 цінностей. Досліджуваному необхідно оцінити цінності за запропонованою шкалою: від -1 (цінність, яка протилежна поглядам респондента) до 7 (цінність, яка для нього є найбільш значущою). Спочатку досліджуваний обирає найбільш значущі $\mathrm{i}$ найменш значущі для нього цінності, а потім оцінює інші цінності в межах визначеного методикою діапазону. Обробка отриманих результатів здійснювалась за допомогою методів математичної статистики (включно з критерієм Фішера та критерієм Стьюдента).

Дослідження проводилось серед студентів Вінницького державного педагогічного університету імені Михайла 
Коцюбинського впродовж 2020-2021 років. Обсяг вибірки - 255 осіб віком від 18 до 22 років. Обробка результатів здійснювалась за допомогою програми Microsoft Excel окремо для двох груп здобувачів вищої освіти - студентів-волонтерів (131 особа) та студентів, які не брали участі у волонтерській діяльності (124 особи).

Обговорення результатів. У результаті проведеного дослідження та подальшої статистичної обробки його результатів було встановлено, що для студентів-волонтерів найбільш значущими нормативними цінностями (в дужках зазначені середні бали) $є$ : доброзичливість $(4,65)$, безпека $(4,58)$, досягнення $(4,53)$, самостійність (4,42), конформність $(4,39)$, гедонізм $(4,26)$, універсалізм $(4,19)$. Менш значущими є такі цінності, як: стимуляція $(3,70)$, влада $(3,63)$, традиції $(3,54)$.

У студентів, які не займаються волонтерською діяльністю, ієрархія нормативних цінностей $\epsilon$ такою: безпека $(4,61)$, доброзичливість $(4,43)$, конформність $(4,42)$, досягнення $(4,30)$, гедонізм $(4,24)$, універсалізм $(4,23)$, самостійність $(4,22)$, стимуляція $(3,80)$, традиції $(3,60)$, влада $(3,59)$.

Узагальнені результати дослідження представлені на рисунку 1.

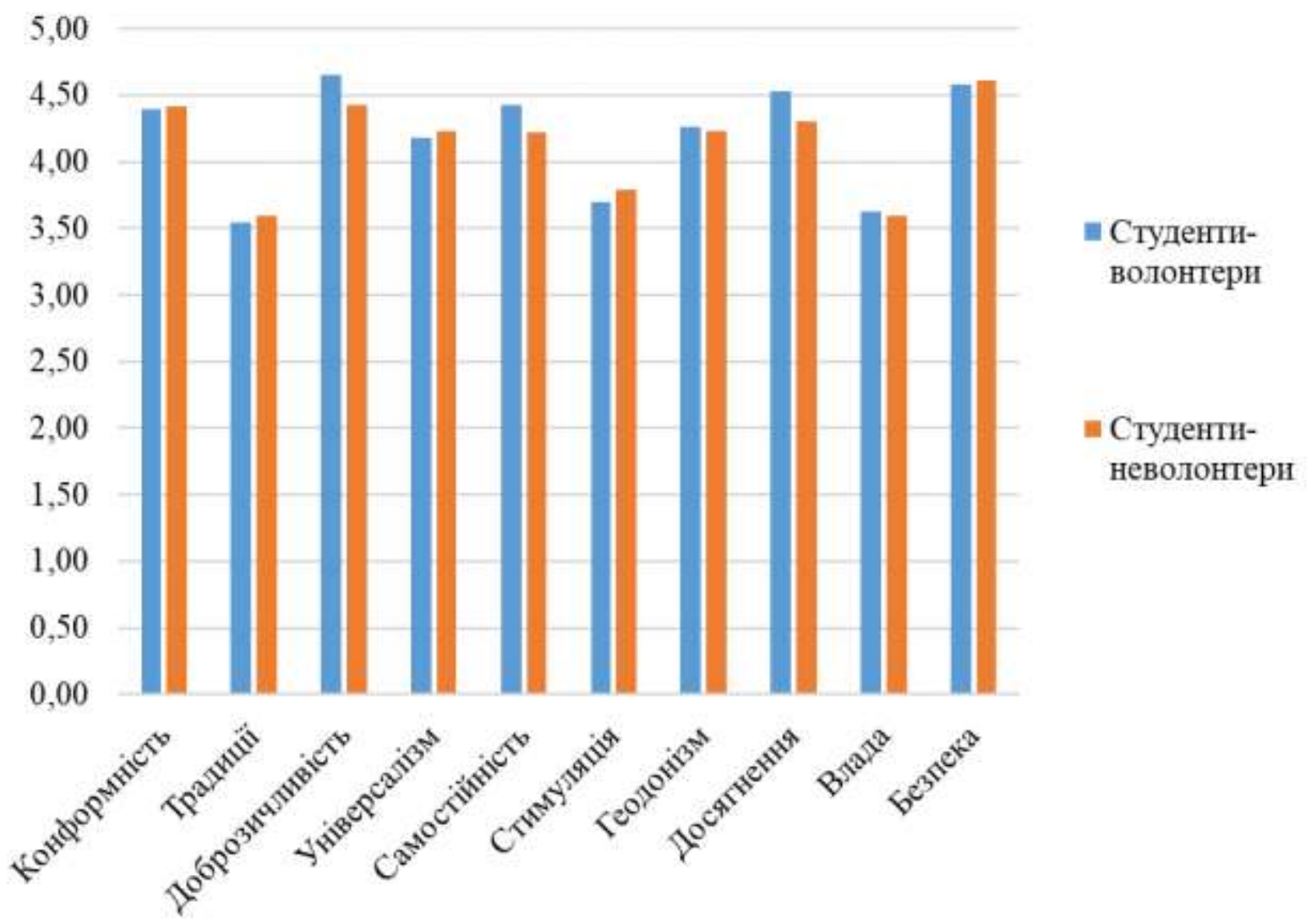

Рис. 1. Структура нормативних цінностей (середній бал) студентівволонтерів і студентів, які не займаються волонтерською діяльністю 
На основі отриманих у процесі дослідження даних був здійснений порівняльний аналіз нормативних цінностей студентівволонтерів (С-В) і студентів, які не займаються волонтерською діяльністю (С-НВ) (табл. 1). Порівняння здійснювалося на основі середніх значень і рангових показників значущості нормативних цінностей для обох груп студентів.

Таблиияя 1

Порівняльний аналіз нормативних цінностей студентівволонтерів (C-B) і студентів, які не займаються волонтерською діяльністю (С-НВ)

\begin{tabular}{|c|l|c|c|c|c|}
\hline \multirow{2}{*}{ № } & \multirow{2}{*}{ Типи цінностей } & \multicolumn{2}{|c|}{ Середні значення } & \multicolumn{2}{c|}{ Рангові показники } \\
\cline { 3 - 6 } & & $\mathrm{C}-\mathrm{B}$ & $\mathrm{C}-\mathrm{HB}$ & $\mathrm{C}-\mathrm{B}$ & С-НВ \\
\hline 1 & Доброзичливість & 4,65 & 4,43 & 1 & 2 \\
\hline 2 & Безпека & 4,58 & 4,61 & 2 & 1 \\
\hline 3 & Досягнення & 4,53 & 4,30 & 3 & 4 \\
\hline 4 & Самостійність & 4,42 & 4,22 & 4 & 7 \\
\hline 5 & Конформність & 4,39 & 4,42 & 5 & 3 \\
\hline 6 & Гедонізм & 4,26 & 4,24 & 6 & 5 \\
\hline 7 & Універсалізм & 4,19 & 4,23 & 7 & 6 \\
\hline 8 & Стимуляція & 3,70 & 3,80 & 9 & 8 \\
\hline 9 & Влада & 3,63 & 3,59 & 8 & 10 \\
\hline 10 & Традиції & 3,54 & 3,60 & 10 & 9 \\
\hline
\end{tabular}

Найбільш значущими як за абсолютними величинами, так і за ранговими показниками в обох групах студентів виявилися цінності «доброзичливість» та «безпека». Фактично це означає, що доброзичливість, яка сфокусована на благополуччі в щоденній взаємодії з близькими людьми, та безпека для інших людей і для себе як похідна від базових індивідуальних та групових потреб (Карандашев, 2004: 29-30) є одними з основних пріоритетів сучасного студентства.

Найбільші відмінності між студентами-волонтерами і студентами, які не беруть участь у волонтерській діяльності, спостерігаються у значущості такого типу цінностей, як «досягнення» (відповідно, 4,53 і 4,30 балів). Такі цінності відображають прагнення до особистого успіху через демонстрацію компетентності, що супроводжується соціальним схваленням (Карандашев, 2004: 28). На наш погляд, це свідчить як про соціальну активність студентівволонтерів, так і про певне нехтування суспільною думкою з боку студентів, які не практикують волонтерську діяльність. 
Дещо відрізняється також ставлення студентів-волонтерів i студентів, які не беруть участь у волонтерській діяльності, до групи цінностей «самостійність»: середній показник значущості цих цінностей для перших становить 4,42 бали, для других - 4,22 бали. Пріоритетом для цього типу цінностей $є$ самостійність мислення і вибору способів поведінки (Карандашев, 2004: 28-29), що, очевидно, є характерним для будь-якого виду соціальної активності, зокрема й для волонтерської. Помітна абсолютна різниця спостерігається і в показниках значущості такої групи цінностей, як «доброзичливість» (відповідно, 4,65 і 4,43 бали). Цей «просоціальний» тип цінностей вважається похідним від потреби в позитивній взаємодії, а його мотиваційна мета - збереження благополуччя людей, з якими індивід особисто контактує (Карандашев, 2004: 29).

Порівняно невелика абсолютна різниця, але вже на користь студентів, які не займаються волонтерською діяльністю (3,80 балів на противагу 3,70 балів), виявлена у значущості такого типу цінностей, як «стимуляція». Очевидно, студенти-волонтери меншою мірю потребують стимуляції для підтримання оптимального рівня активності.

Інші типи цінностей (безпека, конформність, гедонізм, універсалізм, влада, традиції) характеризуються дуже близькими значеннями середніх балів і рангових позицій. Це свідчить про схоже ставлення студентів до вказаних груп цінностей незалежно від участі у волонтерській діяльності. Водночас варто відзначити, що значущість таких груп цінностей, як стимуляція, влада, традиції, характеризується невисокими абсолютними показниками, що, очевидно, свідчить про їхню порівняно незначну важливість у житті сучасного студентства.

Керуючись рекомендаціями щодо вибору критерію визначення статистичної значущості відмінностей між двома незалежними вибірками (Боснюк, 2020: 85-86), ми попередньо здійснили перевірку даних в обох досліджуваних вибірках на відповідність закону нормального розподілу та рівність (гомогенність) дисперсій.

Для перевірки даних на відповідність закону нормального розподілу ми застосували критерій С. І. Пустильника, згідно з яким розподіл вважається нормальним, якщо показники асиметрії (А) та ексцесу (Е) менші за свої критичні значення ( $\mathrm{A}_{\text {крит }}$ i $\mathrm{E}_{\text {крит }}$ ) (Боснюк, 2020: 43). Проведені розрахунки засвідчили, що в обох вибірках 
(студентів-волонтерів і студентів, які не беруть участь у

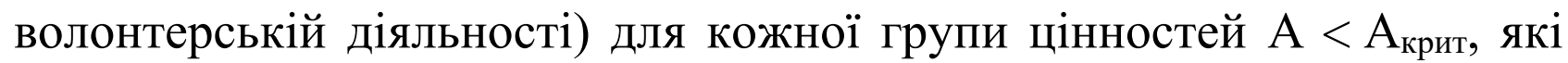

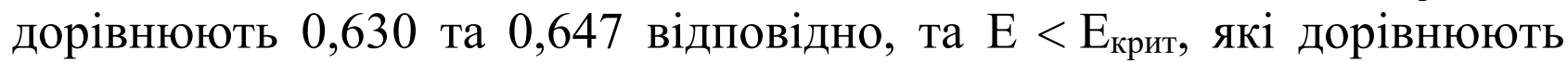
2,022 та 2,071 відповідно.

Перевірка рівності (гомогенності) дисперсій у досліджуваних вибірках здійснювалась за допомогою F-критерію Фішера. Проведені розрахунки, результати яких наведено в таблиці 2, засвідчили, що в

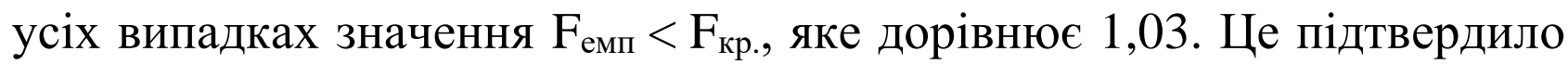
гіпотезу про відповідність емпіричного розподілу даних в обох вибірках закону нормального розподілу та рівність (гомогенність) дисперсій на рівні вірогідності $\mathrm{a}=0,05$, що дало підстави обрати статистичний критерій Стьюдента для визначення відмінностей між показниками значущості різних цінностей для студентів волонтерів $\mathrm{i}$ студентів, які не беруть участь у волонтерській діяльності.

Таблиия 2

Значення F-критерію Фішера для різних типів цінностей

\begin{tabular}{|l|c|c|c|c|c|c|c|c|c|c|}
\hline $\begin{array}{l}\text { Тип } \\
\text { цінностей }\end{array}$ & 1 & 2 & 3 & 4 & 5 & 6 & 7 & 8 & 9 & 10 \\
\hline $\begin{array}{l}\text { F-критерій } \\
\text { Фішера }\end{array}$ & 0,99 & 0,73 & 0,52 & 0,99 & 0,56 & 0,89 & 0,92 & 0,73 & 0,97 & 0,62 \\
\hline
\end{tabular}

Проведені розрахунки засвідчили, що емпіричне значення tкритерію Стьюдента для рівня вірогідності $\mathrm{a}=0,05$ більше за критичне для двох типів цінностей: «досягнення» ( $\left.\mathrm{t}_{\text {емп. }}=2,081>\mathrm{t}_{\mathrm{kp}}=1,980\right)$ та «доброзичливість» $\left(\mathrm{t}_{\text {емп. }}=2,023>\mathrm{t}_{\text {кр. }}=1,980\right)$. Це дає підстави стверджувати, що саме за ставленням до цих груп цінностей студенти-волонтери відрізняються від студентів, які не займаються волонтерською діяльністю. Хоча слід відзначити, що значущість групи цінностей «доброзичливість» для студентів, які не беруть участь у волонтерській діяльності, також є доволі високою. В інших випадках, у тому числі за помітної різниці в абсолютних значеннях середніх показників (групи цінностей «самостійність» і «стимуляція»), емпіричне значення t-критерію Стьюдента менше за критичне.

Загалом слід відзначити відносно велику величину середніх балів за більшістю груп цінностей, що може бути непрямим свідченням достатнього рівня обізнаності студентів із різними типами нормативних цінностей. 
Висновки і перспективи. Волонтерська діяльність студентів детермінується комплексом соціально-психологічних чинників, особливу роль серед яких відіграють ціннісні орієнтації. Проведене дослідження нормативних цінностей студентів педагогічного університету свідчить про існування цілої низки типів цінностей (безпека, конформність, гедонізм, універсалізм, влада, традиції), які характерні для студентства загалом. При цьому найбільш значущими групами цінностей для всіх студентів є доброзичливість і безпека, а найменш значущими - стимуляція, влада й традиції.

Основними групами цінностей, за якими студенти-волонтери відрізняються від студентів, котрі не беруть участі у волонтерській діяльності, є досягнення та доброзичливість. Використання критерію Стьюдента підтвердило статистичну значущість відмінностей між показниками ставлення студентів-волонтерів і неволонтерів до цих типів цінностей. Очевидно, це пов'язано як із соціальною активністю студентів-волонтерів, що супроводжується соціальним схваленням, так і з їхнім прагненням оберігати благополуччя людей, яким вони допомагають.

У ставленні до інших груп цінностей (самостійність, стимуляція) також спостерігаються певні відмінності між студентами досліджуваних груп. Проте за помітної різниці в абсолютних середніх показниках ці відмінності не досягають рівня статистичної значущості. Варто також відзначити достатній рівень обізнаності сучасних студентів 3 різними типами нормативних цінностей.

Перспективи подальших досліджень вбачаємо у вивченні динаміки змін ієрархічної структури нормативних цінностей студентів-волонтерів i здійсненні порівняльного аналізу особливостей становлення їхніх ціннісних орієнтацій на емотивному рівні.

\section{Література} НУЦЗУ .

1. Боснюк, В. Ф. (2020). Математичні методи в психології. Харків:

2. Бочелюк, В. В. (2012). Психологія вивчення ціннісних орієнтацій сучасної особистості. Теорія і практика сучасної психологї̈, 4, 5-9.

3. Буздуган, Я., Никонович, О. (2013). Еволюція світового волонтерського руху. Віче 12, 7-10.

4. Водяна, О.В. (2020). Закордонний досвід благодійної діяльності студентської молоді. Психологія та педагогіка: необхідність впливу науки на 
розвиток практики в Україні. Збірник тез наукових робіт учасників міжнародної науково-практичної конференції, 102-106. Львів.

5. Галузяк, В. М. (2009). Ціннісні орієнтації в структурі особистісних чинників педагогічного спілкування. Наукові записки Вінницького державного педагогічного університету імені Михайла Коцяюбинського. Серія: педагогіка $i$ психологія, 29, 86-92.

6. Долинська, Л. В., Максимчук, Н. П. (2008). Психологія ціннісних орієнтацій майбутнього вчителя. Кам'янець-Подільський: ФОП Сисин О. В.

7. Драченко, В. В. (2008). Виховання морально-ціннісних орієнтацій підлітків засобами творів світової художньої культури: автореф. дис. ... канд. пед. наук. Київ: Ін-т пробл. виховання АПН України.

8. Карандашев, В. Н. (2004). Методика Шварца для изучения ценностей личности: концепция и методическое руководство. Санкт-Петербург: Речь.

9. Колотило, М. О. (2020). Онлайн-волонтерство у сучасному світі: особливості та актуальні практики. Сочіальна робота і сучасність: теорія та практика професійного й особистісного розвитку соиіального прачівника: матеріали Десятої Міжнародної науково-практичної конференизї. 97-99. Київ.

10. Марчук, В., Стаднік, Н. (2018). Сутнісні характеристики ціннісних орієнтацій студентів. Науковий вісник Миколаївського національного університету імені В. О. Сухомлинського. Серія: Педагогічні науки, 1, 183-187.

11. Москаленко, О.В. (2013). Структурні компоненти ціннісно-смислової сфери особистості. Вісник НТУУ «КПІ». Серія: Філософія. Психологія. Педагогіка. 1, 91-98.

12. Павліченко, А. (2005). Ціннісні орієнтації у системі становлення особистості. Психологія і суспільство, 4, 98-120.

13. Панчук, Н. П. (2014). Особистісні ціннісні орієнтації як результат самовизначення майбутнього фахівця. Проблеми сучасної психологї, 23, 532541.

14. Подолянчук, Д. С. (2020). Ціннісні орієнтації студентської молоді як предмет соціально-психологічного дослідження. Габітус, 19, 263-270.

15. Сошина, Ю. М. (2016). Психологічні особливості формування ціннісносмислових настановлень у підлітковому віці: дис. ... канд. психол. наук. 19.00.07. Київ: Нац. пед. ун-т імені М. П. Драгоманова.

16. Тохтарова, I. М. (2014). Волонтерський рух в Україні: шлях до розвитку громадянського суспільства як сфери соціальних відносин. Теорія та практика державного управління і місцевого самоврядування. 2. http://el-zbirndu.at.ua/2014_2/5.pdf

17. Федух, I. С. (2011). Визначення змісту поняття «ціннісна орієнтація»у сучасній психолого-педагогічній науці. Вісник Національної академї̈ Державної прикордонної служби http://nbuv.gov.ua/UJRN/Vnadps_2011_3_25

18. Akın, M. A. (2018). The pre-service teachers value orientations. Educational Research and Reviews, 13(6), 173-187. 
19. Bojović, Ž., Vasilijević, D., \& Sudzilovski, D. (2015). Values and value orientations of students, future primary school teachers and preschool teachers. Croatian Journal of Education: Hrvatski časopis za odgoj i obrazovanje, 17, 11-35.

20. Boros, A., Marian, L. O., \& Mateevici, V. (2019). Promoting volunteering and raising awareness of volunteerings importance. Hyperion Economic Journal, 7(2), 19-24.

21. Botalova, O. B., $\quad$ Osipova, S. V., $\quad$ Asenova, N. S., $\quad$ Kenenbaeva, M. A., Kuderina, A. Y., Zholtaeva, G., ... \& Azanbekova, G. (2016). Value Orientations of Future Teachers-Researchers. International Journal of Environmental and Science Education, 11(17), 10279-10288.

22. Clary, E. G. \& Snyder, M. (1999). The motivations to volunteer: Theoretical and practical considerations. Current Directions in Psychological Science, 8(5), 156159.

23. Esmond, J., \& Dunlop, P. (2004). Developing the Volunteer Motivation Inventory to Assess the Underlying Motivational Drives of Volunteers in Western Australia. Australia: CLAN WA Inc.: Available at: https://citeseerx.ist.psu.edu/ viewdoc/download?doi=10.1.1.734.3555\&rep=rep1\&type=pdf

24. Haski-Leventhal, D., Paull, M., Young, S., MacCallum, J., Holmes, K., Omari, M., ... \& Alony, I. (2020). The multidimensional benefits of university student volunteering: Psychological contract, expectations, and outcomes. Nonprofit and Voluntary Sector Quarterly, 49(1), 113-133.

25. Schwartz, S. H. \& Bilsky, W. (1994). Values and personality. European Journal of Personality, 8, 163-181.

26. Schwartz, S. H. (1992). Universals in the structure and content of values: Theoretical advances and empirical tests in 20 countries. In M. P. Zanna (Eds.), Advances in Experimental Social Psychology, 25, 1-65. Orlando, FL: Academic.

\section{References}

1. Bosniuk, V. F. (2020). Matematychni metody v psykholohii [Mathematical methods in psychology]. Kharkiv: NUTsZU [in Ukrainian].

2. Bocheliuk, V. V. (2012). Psykholohiia vyvchennia tsinnisnykh oriientatsii suchasnoi osobystosti [Value orientations of modern psychology of personality]. Teoriia $i$ praktyka suchasnoi psykholohii - Theory and practice of modern psychology, 4, 5-9 [in Ukrainian].

3. Buzduhan, Ya., Nykonovych, O. (2013). Evoliutsiia svitovoho volonterskoho rukhu [The evolution of the global volunteer movement]. Viche Chamber, 12, 7-10 [in Ukrainian].

4. Vodiana, O. V. (2020). Zakordonnyi dosvid blahodiinoi diialnosti studentskoi molodi [Foreign experience of charitable activity of student youth]. Proceedings from International Scientific Conference: Mizhnarodna naukovopraktychna konferentsiia [Psykholohiia ta pedahohika: neobkhidnist vplyvu nauky na rozvytok praktyky $v$ Ukraini] - International Scientific-Practical Conference "Psychology and pedagogy: the need for the influence of science on the development of practice in Ukraine», 102-106. Lviv [in Ukrainian]. 
5. Haluziak, V. M. (2009). Tsinnisni oriientatsii v strukturi osobystisnykh chynnykiv pedahohichnoho spilkuvannia [Value orientations in the structure of personal factors of pedagogical communication]. Naukovi zapysky Vinnytskoho derzhavnoho pedahohichnoho universytetu imeni Mykhaila Kotsiubynskoho. Seriia: pedahohika $i$ psykholohiia - Scientific notes of Vinnytsia State Pedagogical University named after Mykhailo Kotsyubynsky. Series: pedagogy and psychology, 29, 86-92 [in Ukrainian].

6. Dolynska, L. V., Maksymchuk, N. P. (2008). Psykholohiia tsinnisnykh oriientatsii maibutnoho vchytelia [Psychology of value orientations of the future teacher]. Kamianets-Podilskyi: FOP Sysyn O. V. [in Ukrainian].

7. Drachenko, V. V. (2008). Vykhovannia moralno-tsinnisnykh oriientatsii pidlitkiv zasobamy tvoriv svitovoi khudozhnoi kultury [Development of moral orientations among teenagers by the means of education through the world art masterpieces]. Extended abstract of candidate's thesis. Kyiv: Institute of problems education APS of Ukraine [in Ukrainian].

8. Karandashev, V. N. (2004). Metodika SHvarca dlya izucheniya cennostej lichnosti: koncepciya i metodicheskoe rukovodstvo [Schwartz's method for studying personality values: concept and methodical guide]. Cankt-Peterburg: Rech' [in Russian].

9. Kolotylo, M. O. (2020). Onlain-volonterstvo u suchasnomu sviti: osoblyvosti ta aktualni praktyky [Online volunteering in the modern world: features and current practices]. Proceedings from International Scientific Conference: $X$ Mizhnarodna naukovo-praktychna konferentsiia [Sotsialna robota $i$ suchasnist: teoriia ta praktyka profesiinoho y osobystisnoho rozvytku sotsialnoho pratsivnyka] The Xth International Scientific-Practical Conference: «Social work and modernity: theory and practice of professional and personal development of a social worker», 97-99. Kyiv [in Ukrainian].

10. Marchuk, V., Stadnik, N. (2018). Sutnisni kharakterystyky tsinnisnykh oriientatsii studentiv [Essence characteristics of the students' value orientations]. Naukovyi visnyk Mykolaivskoho natsionalnoho universytetu imeni V. O. Sukhomlynskoho. Seriia: Pedahohichni nauky - Scientific Bulletin of V. O. Sukhomlynskyi Mykolaiv National University. Pedagogical Sciences, 1, 183187 [in Ukrainian].

11. Moskalenko, O. V. (2013). Strukturni komponenty tsinnisno-smyslovoi sfery osobystosti [Structural components of value-sense field of individual]. Visnyk NTUU «KPI». Seriia: Filosofiia. Psykholohiia. Pedahohika - Bulletin of NTUU "KPI". Series: Philosophy. Psychology. Pedagogy, 1, 91-98 ]in Ukrainian].

12. Pavlichenko, A. (2005). Tsinnisni oriientatsii u systemi stanovlennia osobystosti [Value orientations in the system of personality formation]. Psykholohiia i suspilstvo - Psychology and society, 4, 98-120 [in Ukrainian].

13. Panchuk, N. P. (2014). Osobystisni tsinnisni oriientatsii yak rezultat samovyznachennia maibutnoho fakhivtsia [Value orientations of personality as the result of future specialist's self-determination]. Problemy suchasnoi psykholohii Problems of modern psychology, 23, 532-541 [in Ukrainian]. 
14. Podolianchuk, D. S. (2020). Tsinnisni oriientatsii studentskoi molodi yak predmet sotsialno-psykholohichnoho doslidzhennia [Valuable orientations of student youth as an object of socio-psychological research]. Habitus - Habitus, 19, 263-270 [in Ukrainian].

15. Soshyna, Yu. M. (2016). Psykholohichni osoblyvosti formuvannia tsinnisnosmyslovykh nastanovlen u pidlitkovomu vitsi [Psychological peculiarities of formation of value-semantic options during adolescence period]. Extended abstract of candidate's thesis. Kyiv: Nacionalnyj pedagogichnyj universytet imeni M. P. Dragomanova [in Ukrainian].

16. Tokhtarova, I. M. (2014). Volonterskyi rukh v Ukraini: shliakh do rozvytku hromadianskoho suspilstva yak sfery sotsialnykh vidnosyn [Volunteer movement in Ukraine: way for the development of civil society as sphere of social relations]. Teoriia ta praktyka derzhavnoho upravlinnia $i$ mistsevoho samovriaduvannia Theory and practice of public administration and local self-government. 2 [in Ukrainian].

17. Fedukh, I. S. (2011). Vyznachennia zmistu poniattia "tsinnisna oriientatsiia" u suchasnii psykholoho-pedahohichnii nautsi [Defining the meaning of the concept of "value orientation" in modern psychological and pedagogical science]. Visnyk Natsionalnoi akademii Derzhavnoi prykordonnoi sluzhby Ukrainy Bulletin of the National Academy of the State Border Guard Service of Ukraine, 3 [in Ukrainian].

18. Akın, M. A. (2018). The pre-service teachers value orientations. Educational Research and Reviews,13(6), 173-187.

19. Bojović, Ž., Vasilijević, D., \& Sudzilovski, D. (2015). Values and value orientations of students, future primary school teachers and preschool teachers. Croatian Journal of Education: Hrvatski časopis za odgoj i obrazovanje, 17, 11-35.

20. Boros, A., Marian L. O. \& Mateevici, V. (2019). Promoting volunteering and raising awareness of volunteerings importance. Hyperion Economic Journal, 7(2), 19-24.

21. Botalova, O. B., Osipova, S. V., Asenova, N. S., Kenenbaeva, M. A., Kuderina, A. Y., Zholtaeva, G., ... \& Azanbekova, G. (2016). Value Orientations of Future Teachers-Researchers. International Journal of Environmental and Science Education, 11(17), 10279-10288.

22. Clary, E. G. \& Snyder, M. (1999). The motivations to volunteer: Theoretical and practical considerations. Current Directions in Psychological Science, 8(5), 156159.

23. Esmond, J., \& Dunlop, P. (2004). Developing the Volunteer Motivation Inventory to Assess the Underlying Motivational Drives of Volunteers in Western Australia. Australia: CLAN WA Inc.

24. Haski-Leventhal, D., Paull, M., Young, S., MacCallum, J., Holmes, K., Omari, M., ... \& Alony, I. (2020). The multidimensional benefits of university student volunteering: Psychological contract, expectations, and outcomes. Nonprofit and Voluntary Sector Quarterly, 49(1), 113-133.

25. Schwartz, S. H. \& Bilsky, W. (1994). Values and personality. European Journal of Personality, 8, 163-181. 
26. Schwartz, S. H. (1992). Universals in the structure and content of values: Theoretical advances and empirical tests in 20 countries. In M. P. Zanna (Eds.), Advances in Experimental Social Psychology, 25, 1-65. Orlando, FL: Academic.

Received: 12.04 .2021

Accepted: 29.04.2021 